\title{
Competency Test of Engineering Drawing Design Engineering Using the Online Method
}

\author{
W. Wilarso ${ }^{1^{*}}$, Alfiyah Afriliyanti ${ }^{2}$, Jujun Juniadi ${ }^{2}$, M. Mujiarto ${ }^{3}$ \\ ${ }^{1}$ Department of Mechanical Engineering, Sekolah Tinggi Teknologi Muhammadiyah Cileungsi, Bogor, \\ Indonesia \\ ${ }^{2}$ SMK Teknologi YAF, Banjar, West Java, Indonesia \\ ${ }^{3}$ Department of Mechanical Engineering, University of Muhammadiyah Tasikmalaya, Tasikmalaya, \\ Indonesia \\ *Corresponding author: wilarso@sttmcileungsi.ac.id
}

\section{ARTICLE INFO}

Article history

Received May 2, 2020

Revised May 19, 2020

Accepted May 26, 2020

Available Online May 31, 2020

Keywords

Pandemi COVID-19

Competency Test

workforce

\begin{abstract}
The COVID-19 pandemic made all teaching and learning processes at SMK YAF-Banjar conducted online, to prevent the widespread transmission of Virus-COVID-19. Students continue to learn at home according to the schedule of lessons from school. The competency test of students' machine design drawings conducted by the school is done online so that the competencies of students in grade 12 meet the educational standards and requirements for graduating students to face the workforce. The purpose of the online competency test is to test students' abilities in terms of machine image design. The method used in the student competency test is to contact every student who studies at SMK YAF. The results and discussion in this competency test the results carried out have not been maximized, due to signal constraints where students live, then from the online competency test 3 criteria are communicated including, 1) knowledge, 2) skills, 3) attitude. From the results of the assessment of knowledge and skills the average value is 75 . From this value it must still be improved in terms of knowledge and skills. In the knowledge, criteria is an understanding of SOP and applying quality standards of work, while for skills are the results, including 3D arrangement drawings, detailed drawings of $2 \mathrm{D}$ components, projections and cuts, grading, linear and geometrical tolerances, markings of work and roughness prices.
\end{abstract}

This is an open access article under the CC-BY-SA license.

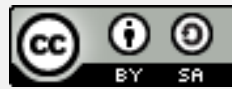

\section{Introduction}

The teaching and learning process carried out by SMK YAF-Banjar during the COVID-19 pandemic was carried out online. The student competency test is also conducted online. Where students are given 12-14 hours to work on the competency test to make the pulley drive that has been determined by the Ministry of Education and Culture. 
The duration students are asked to draw 2D and 3D [1] by manual and computerized. The ability to visualize in three dimensions is cognitive skills related to success in engineering. Spatial visualization skills and their correlation with student success have received a lot of attention in technical education [2]. The ability of students must be able to visualize how to design machine drawings [3]. In the implementation of designing machine drawings [4] students work on using laptops from their homes. To determine the results done by students, the YAF Vocational School provides the mandate of external examiners to assess students incompetency tests [4]. So that incompetency tests get maximum results in the teaching and learning process [5] at YAF Vocational School. Drawing machines for vocational students must have an artistic spirit, by mastering images, can express themselves in all fields [6].

This study is motivated by a great concern about the future and the sustainability of Technical Images [7] at all levels of society and our education system especially in technical vocational schools. Concerns stem from poor performance, low practice skills, and a decrease in performance and exams [8].

\section{Methods}

Methods in online competency testing [9] his is by contacting students one by one through the cell phone network. Figure 1 explains the communication flow between the YAF Vocational Coordinator and the external examiner team.

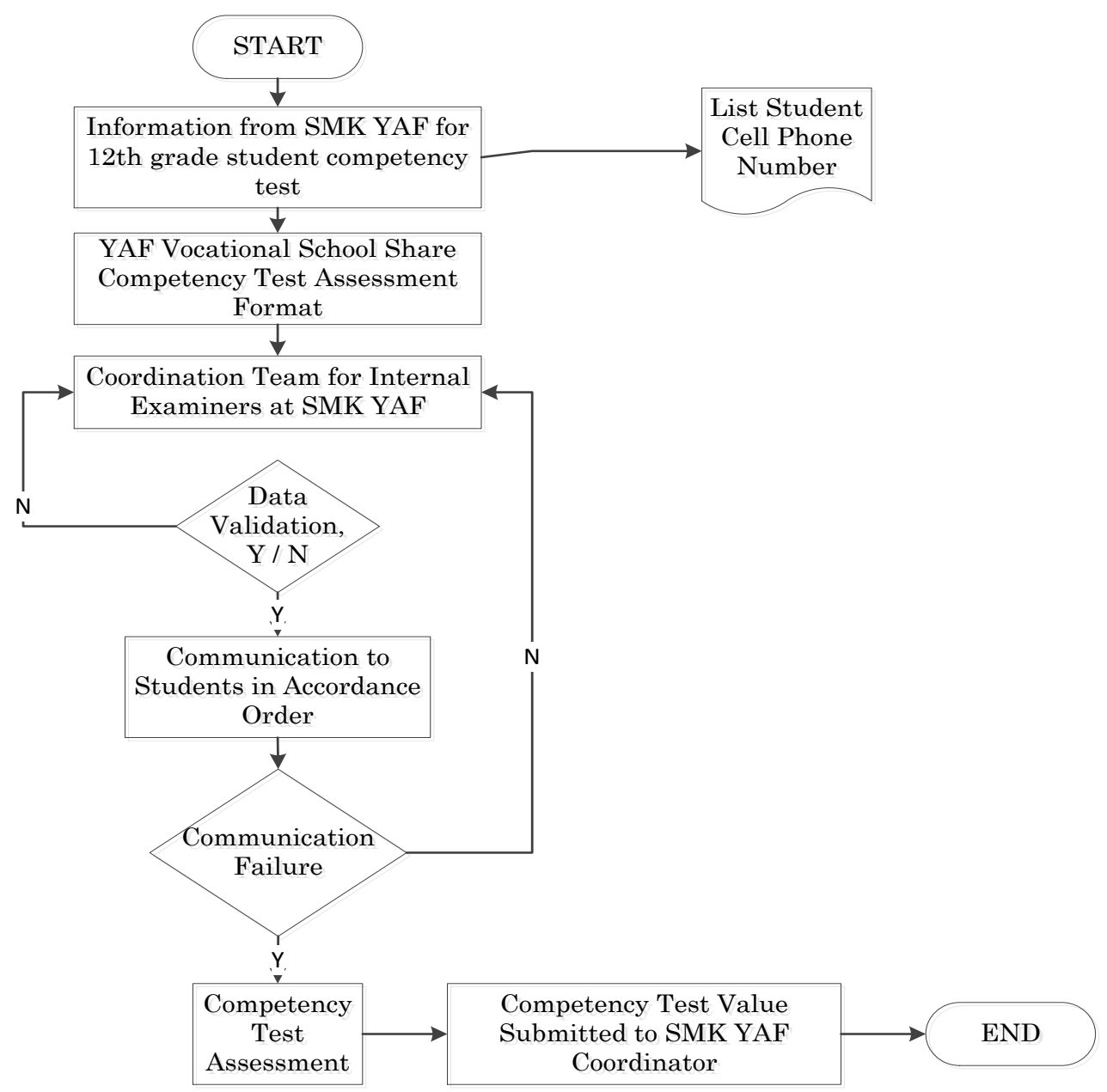

Figure 1. The flow of competency tests for YAF Vocational students 


\section{Results and Discussion}

Incompetency test research from the aspect of knowledge there are 10 indicators of competency achievement [8], of the 10 indicators there are 2 things that are of concern in the world of work. Safety and health in the design of this machine drawings must also be considered because drawing this part of the construction that must be taken into account in terms of safety [10]. 1) understand the SOP of the tasks being carried out to ensure a safe work environment [11]. This is very important for YAF Vocational students, why is that in the world of work must understand SOP [12]. In designing machine drawings students must understand the SOP before operating a computer, when operating and after operating a computer. Occupational Health Safety is everywhere also regulated in Law No. 1, 1970 [13].

Before operating a computer students must prepare for the safety of the students themselves [14], from the use of PPE (Personal Protective Equipment), such as shoes, helmets, safety glasses, if working outside the classroom, if in the classroom must use safety shoes. Then understand the potential dangers in the classroom, including potential fall of plasterboard, falling lights, falling tiles, falling blackboards, electrocution, stumbling objects, snagging cables, stumbling. The basic understanding that must start from the environment of Vocational High Schools and High Schools.

1. Checking the computer before it is operated by students is a condition of computer hardware, computer equipment (power cable, cable to the monitor, printer cable), printer. All of the equipment must be in complete condition and nothing is lacking. Why should check the computer equipment, if there is an incomplete then, the computer can not be operated and the impact is the processing time will be longer.

2. Checking the computer after the operation, to find out the computer is working properly, according to the specifications needed for designing the machine image, and keep a distance to face the monitor.

3. After operating the computer, what must be done is to turn off the computer following the procedure, unplug the power cable to the power outlet, turn off the MCB (miniature circuit breaker) for the main panel, so that all equipment that is not in use, does not have electric current and secures computer equipment.

Page 2) apply the standard procedure for the quality of work at work [15], an important point in this case, students are required to be able to apply it in school.

Things students must do are: a) Make a plan in carrying out the work to be done, b) Know the function of the object to be made, c). Knowing how things work to be made, d). Knowing the material to be used, e) Knowing the risk of danger if the object has been used, f) Knowing how to care for the object to be used at work. g) know the life of the component that has been made from the test image and the actual test of the object itself. h) making SOPs for the operation and maintenance of workpieces, i) making tool maintenance guidelines. 
Table 1. Indicators of achieving machine design competency.

\begin{tabular}{l} 
Indicators of Competency Achievement \\
\hline Understand SOP tasks that are being done to ensure a safe work \\
environment \\
Implement standard work quality procedures at work \\
Identify image demands \\
Components, assemblies or objects are recognized on-demand \\
The designation of the size is identified according to the field of work \\
Symbols on images can be recognized \\
Computer applications and computer system principles are understood \\
Prepare CAD support system tools [16] \\
Understanding 2D drawing with CAD [17] \\
Understand how to create and edit 3D image models [18]
\end{tabular}

\subsection{Value aspects of knowledge of competency test.}

From the value of knowledge aspects, after competency testing [19] indicate there are some values below the minimum, this is not as an obstacle in the competency test. But it needs to be evaluated from all aspects of learning from the beginning to the final level, especially from the teaching and learning process. A road map in the competency test process [20] must also be understood by the school, so students do not experience obstacles in the implementation of competency tests. From Figure 2 a total of 17 students who conducted the competency test were rated highly competent, from meeting the assessment criteria. In this aspect of knowledge, students explain verbally what they are working on, whether in the form of presentations or explain using the method to be made. Then from the 10 questions to be explained in front of the examiner to know the ability to present the process to be done.

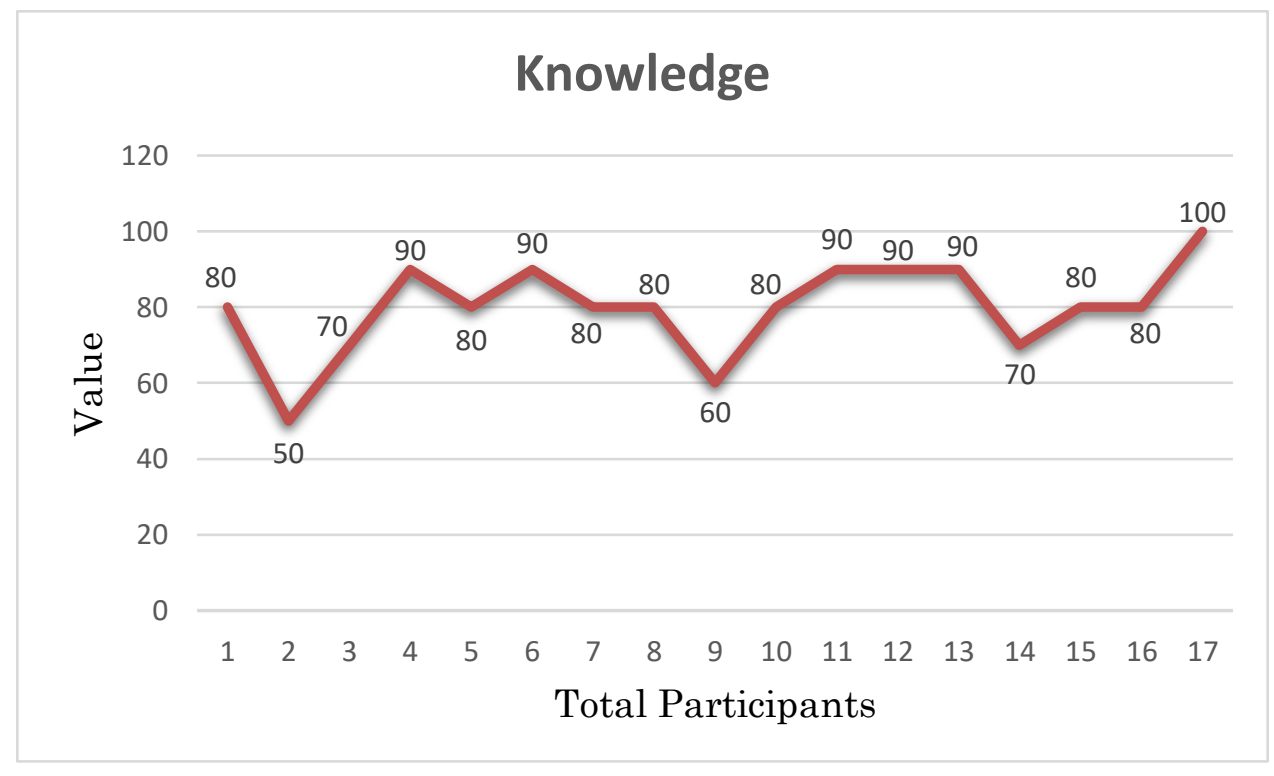

Figure 2. Value Assessment of Knowledge Aspects 


\subsection{Value of Skill Aspects.}

The value of this skill aspect determines the level of student understanding [21] incompetency tests, where students are tested for ability in the practice of planning machine drawings based on tests from the Ministry of Education and Culture for a predetermined time. In the execution of the competency test. Based on this competency test standard 3 things areat are tested including 1) Preparation, 2) Implementation, 3) Results. Of the three criteria, students must do before the competency test.

1. Number 1 regarding preparation, how students prepare work tools [22], up to the workpiece to be made competency test if needed, if not only instructions that have been determined by the school. This preparation requires correct calculations, such as knowing the object to be drawn.

2. Implementation, in this case students are asked to draw according to the instructions that have been delivered, from starting to draw manually using 80 gsm HVS paper with A4 and A3 measurements. The work steps must be used from the beginning to the end.

3. The results of the implementation of competency tests that have been carried out, how students draw according to instructions. From the results that have been done it must be following the instructions. Then the results must be submitted to the examiner to find out the accuracy of the size, shape, giving symbols to the image [23], marking workmanship in the picture, granting tolerance and geometric in the picture [24], as well as providing information on each component drawn, to make it easier for the operator to work and no longer ask drafter or image operators.

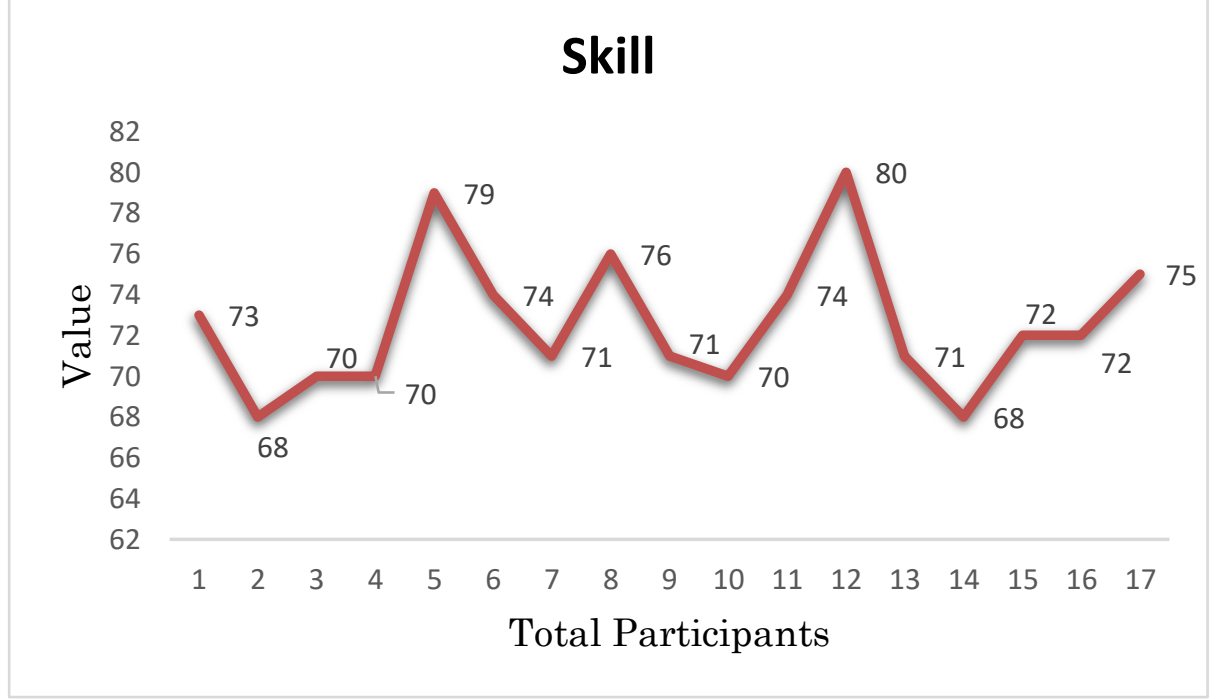

Figure 3. Values for Assessing Skills

Figure 4, described support for the pulley stand, where in the pattern the resulting image is generally following its shape. But there is still a sign of lacking, like:

1. Figure no 1 , in the front view there is a marking of $\varnothing 6 \mathrm{~mm}$ hole diameter, but in the side view there is a cut line symbol, but there is no size on the cut line. This picture shows something to do, but no size is shown.

2. Image no. 2, the diameter of the hole $\varnothing$... If it is not explained in terms of diameter, it will not be worked out even if it has a sign. Then if it is adjusted to the side view picture with that diameter, what is its size. 
3. Image no. 2 connections using a welding machine ... the mark in the figure must be explained that the connection of the plate using a machine.

4. Image no. 3 plate size required how many milli, whether the size of the vertical and horizontal plates are the same, this must be considered in drawing the machine.

This drawing gives information to others clearly and correctly, how about images people can understand and can read the desired needs.

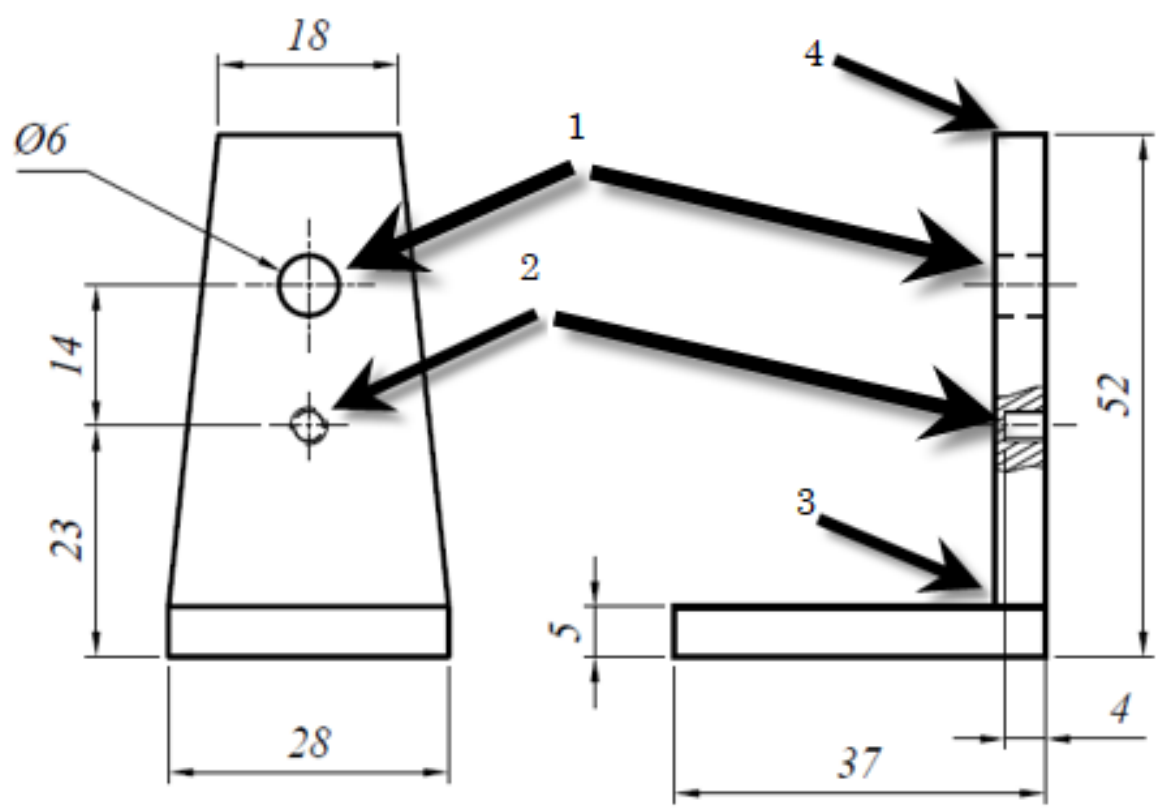

Figure 4. The results of the competency test of the design of a machine image.

Figure 5. Explain the shaft image for the guide pulley holder that has been made. In drawing it if re-evaluated there are 6 points of concern in drawing, including:

1. No. 1. What level of construction does this work start from? If you look at this pivot image there are 3 levels, and each level has a different size. Then the work must be done rough, fine, or threaded work on the surface of the shaft or bolt surface [25].

2. No. The 2 questions are not much different from No. 1. But in No. 2 you must be able to explain the size of the drawing [26] how much is needed...

3. No. 3 is the work of a chamfer, how many angles are needed ... This chamfer is often used in the manufacture of automotive parts [27].

4. No. 4 how many diameters are needed ... does this point need to be threaded or not ... Work on the surface at no. These 4, will the bolt stand be made ... then in M6 what tolerance value is needed [28] and what is the size of the M6.

5. No 5 in this section is there any making of a chamfer .... what must be considered is how many chamfer angles are needed [27]... Is it the same as No. 3, if there are how many in the drawing must be made an angle. Giving a sign of workmanship drafter must pay attention to components that will be made following the function and use.

6. No. 6 there is a diameter that must be conveyed in drawing, but in the process there is no attachment size. This accuracy is needed once, so that there is no failure in the component manufacturing process [29], thereby minimizing damage, as well as reducing production costs. 
Each part of making the shaft, must be considered from every angle, view, and other aspects. Then in terms of tolerance [30] which must be submitted in making the shaft, must also be calculated how much tolerance value is needed. So that when it is used there are no obstacles in the installation, whether it can not be mounted on a stand, too loose or too tight so that you have to return it.

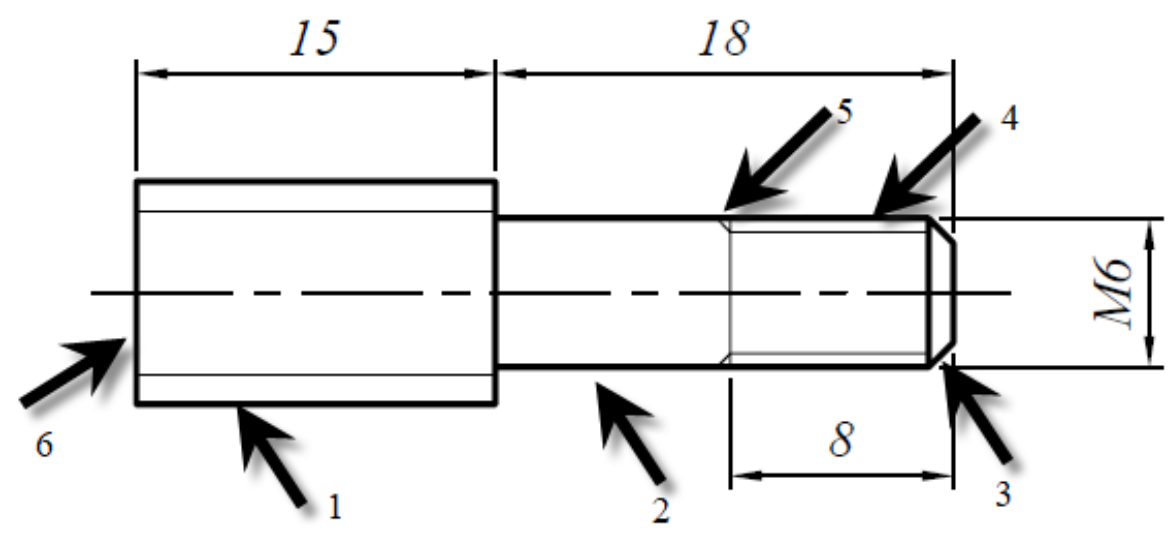

Figure 5. Adjusting pulley shaft.

\section{Conclusion}

With the condition of the COVID-19 pandemic, various ways for teaching and competency testing are done online, there are advantages and disadvantages. In terms of shortcomings that can not interact directly with students, the data used in the competency test is not optimal, constrained by communication networks. which is undergoing a competency test, while in terms of its strengths is preventing the transmission of the COVID-19 virus so that it does not spread, and is more effective in implementation, reducing the use of the budget. From the results of this competency test, it must be improved in terms of work safety in the classroom and outside the classroom, especially in terms of Standard Operating Procedures (SOP), so students can apply it in everyday life. Work quality standard procedures are also further improved to train students to face the world of work after graduating from school. Then from the improvement of learning skills from preparation, implementation, and results to be more focused in theory and practice and try with a shorter time to give students a psychological test. With better results and according to the assessment aspects will produce graduates who are qualified and needed in the world of work. Accuracy in the drawing must also be considered, by providing detailed information in the picture, in every part that works can understand the picture well and there are no mistakes in making, and reduce production costs.

\section{Acknowledgments}

The implementation of the competency test went well, thanks to the help of all parties, especially the Al Falah-Banjar foundation which has appointed a team of external examiners to test SMK YAF students. Thank you to the competency test implementing coordinator who has provided valid data for the testing process. 


\section{References}

[1] F. Naya, J. Jorge, and J. Conesa, "Direct modeling: from sketches to 3d models," Proc. 1st Ibero-American Symp. Comput. Graph., pp. 109-117, 2002.

[2] T. Serdar and R. H. De Vries, "Enhancing spatial visualization skills in engineering drawing course," ASEE Annu. Conf. Expo. Conf. Proc., vol. 122nd ASEE Annual Conference and Exposition: Making Value for Society, no. 122nd ASEE Annual Conference and Exposition: Making Value for Society, 2015.

[3] P. B. Tarigan, “済無No Title No Title,” J. Chem. Inf. Model., vol. 53, no. 9, pp. 16891699, 2013.

[4] G. Zarza, D. Lugones, D. Franco, and E. Luque, "An innovative teaching strategy to understand high-performance systems through performance evaluation," Procedia Comput. Sci., vol. 9, pp. 1733-1742, 2012.

[5] G. E. Loyd and H. M. Koenig, "Assessment for Learning: Formative Evaluations," Int. Anesthesiol. Clin., vol. 46, no. 4, pp. 85-96, 2008.

[6] I. Literat, "'A pencil for your thoughts': Participatory drawing as a visual research method with children and youth," Int. J. Qual. Methods, vol. 12, no. 1, pp. 84-98, 2013.

[7] V. Flusser, Into the Universe of Technical Images Introduction by Mark Poster, vol. 32. 1985.

[8] S. Abdulwahab and A. Usman, "Competencies Required by Technical Drawing Teachers in Technical Colleges," IOSR J. Res. Method Educ., vol. 4, no. 2, pp. 3237, 2014.

[9] The World Health Organization, "Competency and competency assessment," pp. 142-144, 1999.

[10] K. Pekerjaan, U. Dan, P. Rakyat, B. Pengembangan, and S. Daya, "Kementerian pekerjaan umum dan perumahan rakyat badan pengembangan sumber daya manusia," 2016.

[11] SkillMaker, "Workplace safety procedures and instructions," SkillMaker, pp. 1-17, 2014.

[12] C. Reese, "Safe Operating Procedures," Occup. Saf. and Health, pp. 237-244, 2017.

[13] Akerlof, “済無No Title,” J. Chem. Inf. Model., vol. 53, no. 9, pp. 1689-1699, 1970.

[14] A. S. Walker and G. Pearson, "Engineering Drawing," Math. Gaz., vol. 50, no. 373, p. 350, 1966.

[15] T. Package and E. Guide, “Apply quality procedures," vol. 2006, no. June 2006, pp. 64-68, 2007.

[16] "Essentials of 3D CAD for 2D users," pp. 1-29.

[17] I. Irawan M. R and A. H.M, "a Case Study of Autocad 2D Engineering Drawing Performance Among Furniture and Product Design (Bfpd) Students," no. December, pp. 49-57, 2017.

[18] F. Remondino and S. El-hakim, "Image-based 3D modelling: A review," Photogramm. Rec., vol. 21, no. 115, pp. 269-291, 2006.

[19] D. Russo, "Competency Measurement Model," Eur. Conf. Qual. Off. Stat., pp. 1-29, 2016.

[20] J. K. Raju, C. Bagrecha, and C. Ravi Kumar, "Competency Mapping in IT IndustryA Road Map for Future," Adarsh J. Manag. Res., vol. 7, no. 1, p. 20, 2014.

[21] N. Smirnov, N. Nedev, J. Koprinarova, and D. B. Dimitrov, "The permittivity in a magnetic field of thin SiOx layers containing Fe and Ni," Vacuum, vol. 47, no. 9, pp. 1105-1106, 1996. 
[22] M. Makela, N. Nimkulrat, and T. Heikkinen, "Drawing as a research tool: Making and understanding in art and design practice. Academic and professional practice View project Handling Mind: Embodiment, Creativity and Design View project," Stud. Mater. Think., vol. 10, no. May 2015, pp. 1-13, 2014.

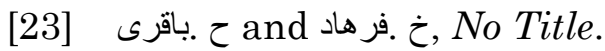

[24] L. W. Foster, "Geometric dimensioning and tolerancing," SAE Tech. Pap., 1968.

[25] Sandvik Coromant, "Threading Aplication Guide," 2012.

[26] M. Rule, "Drawing Indication."

[27] P. P. Kumar, A. M. Potdukhe, M. V. Bitode, and A. B. Belvekar, "Design and manufacturing of double sided automatic chamfering machine," Int. J. Curr. Eng. Technol., vol. 9, no. 03, pp. 416-420, 2019.

[28] ارك نوين - Surface Roughness,” p. 1994, 1994.

[29] P. Scallan, "Drawing interpretation,” Process Plan., pp. 63-108, 2003.

[30] F. Inch, "A . Preferred Sizes in Metric $\mathrm{R}-1$ Preferred Sizes in Metric," pp. 0-25. 